КУЛЬТУРНАЯ АНТРОПОЛОГИЯ

W. Sunderland

\title{
Interethnic Relations and Nationality \\ Policy in Post-Soviet Russia: \\ Western Scholarship Since $1991^{1}$
}

Sunderland

Willard,

Ph. D., професcсор,

Университет

Цинциннати

(Цинциннати, США)
The "nationality question" did not single-handedly undo the Soviet Union, but it was a critical factor in the erosion of state authority during the perestroika years and remains an issue of enormous importance in Russian life and politics today. Given this fact, it's no surprise that the interconnecting topics of state nationality policy and interethnic relations have drawn considerable attention from Western specialists. The closeness of the period to the current day means that the work of historians understandably figures less in this literature than that of scholars in the social sciences, specifically: political scientists, economists, sociologists, and anthropologists. But historians have nonetheless entered the fray, making valuable contributions, in particular in regards to the study of historical memory, which has been a key area affecting social identity and interethnic relations in the post-Soviet decades.

One valuable question to ask of the literature is precisely what Western social scientists have contributed to the analysis of nationality and ethnicity-related questions versus the contributions made by Russian scholars and other specialists from the region. On the one hand, opportunities for academic collaboration and exchange have increased dramatically since end of the USSR. More Russian and Western experts now share contacts, methodologies, and even arguments regarding nationality-related 
issues. They collaborate on research teams and sit on each other's conference panels. In that regard, one can speak of genuine movement towards the formation of a single scholarly community with a shared disciplinary language. Yet it's also true that scholarly differences remain, perhaps most saliently in regards to the key terms of the topic: ethnicity and nationality. For most Western specialists, the two terms represent fundamentally constructed and fluid categories deeply influenced by institutional contexts. Thus nations and ethnicities tend to be treated as "made" rather than "born" and are seen as inherently multifaceted and changing. By and large, however, Russian-based specialists remain less inclined to constructivist interpretations of this sort - or put another way, they tend to be more accepting of what the American sociologist Rogers Brubaker has described as the "realist, substantialist understanding" of nationality, one that regards nations "as real entities, as communities, and as substantial, enduring collectivities"2.

Given this difference, a potential contribution of Western scholarship lies in its extending an alternative conceptual framework to Russian specialists. Besides this, it's also clear that experts from Europe and North America bring an outsider's subjectivity to questions of interethnic relations in Russian space, since they tend to approach the topic, implicitly if not explicitly, through the lens of their own societies' experiences. This, too, has the potential to offer opportunities for debate and constructive exchange. Finally, Western scholars also tend to have a more skeptical view than their Russian counterparts of the supposed distinctiveness of the Russian case. President Vladimir Putin noted in a major 2012 statement on the "national question" that Russia has a unique history of integrating yet also respecting the differences of the various ethnicities of the state, such that Russians today represent both "a single people" and "a multinational society"3. Many Russian-based experts would likely agree with this statement. More experts in the West might disagree or at least challenge some of its implicit assumptions.

The following paper reviews Western scholarship on the questions of nationality politics and interethnic relations in Russia in the post-Soviet decades, starting with an assessment of Western research on the role played by the national factor in the collapse of the Soviet state.

\section{The Nationality Question and the End of the USSR}

At the time of its demise, the Soviet Union was not, formally speaking, an empire. In fact, the Bolshevik architects of the Soviet state, all of whom were ardent anti-imperialists, purposefully fashioned their new country to be the ultimate retort to the Russian Empire of old, not an empire but rather its exact opposite: a multinational union that would build socialism, while at the same time protecting and promoting national cultures ${ }^{4}$.

Yet for all its expressly anti-imperial bearing, the new multinational union nonetheless looked and acted a great deal like the empire it replaced. For one, it sprawled across much of the same territory and consisted of the same two basic parts: a mostly Russian center surrounded by a largely non-Russian periphery. Like the old empire, its institutions remained Russocentric, while Russian remained the dominant language. On the face of it, the new union formally allowed the union republics the right to secede from the country - a boldly democratic innovation compared to the old empire. But the republics were obviously not allowed to use that right. And even the new state's commitment to promoting non-Russian languages, territories, economic regions, and national cultures, 
while radically different from the tsarist approach, was not quite as anti-imperial as it might seem. The USSR was famously supposed to be "national in form, socialist in content," but this slogan was deceptive - or rather, simply beside the point. While Tatarness was encouraged for Tatars and Buryatness for Buryats, the socialism that Tatars and Buryats - and every other national group in the state - were expected to embrace was predicated on Russian norms. As a result, one could be forgiven for being confused. After all, if non-Russians were expected to be non-Russian in form but mostly Russian in content, how non-Russian were they really expected to be?

Given all this, it's perhaps understandable that non-Russians would develop a powerfully anti-imperial critique of Soviet power and ultimately come to see the breakup of the USSR as a process of decolonization ${ }^{5}$. Interestingly, influential Russian critics ultimately ended up in the same spot, concluding that they, the Russians, had themselves been unfairly colonized by the Communist Party, and both these interpretive tendencies came to a head during the perestroika years. As British historian Dominic Lieven has observed, in the mid-to-late 1980s, as Gorbachev began to restructure the economy, both Russians and non-Russians alike began "restructuring" their thinking of themselves, and as they did, they came to view the USSR - a. k. a, "the center," "Moscow," or simply "Soviet power" (sovetskaia vlast') - as the abiding enemy of all their "essential, authentic, [and] natural national aspirations"6. What transpired under perestroika, in effect, was a cognitive shift that redefined the USSR as empire. Once this mental turn took place, especially against the backdrop of profound economic distress, the ruling order rapidly shed legitimacy and soon found itself teetering and then falling apart.

For Western specialists on the USSR, this turn of events was paradoxically both shocking and predictable. On the one hand, the presumption that the Soviet Union was an empire was a commonplace of conservative and to a degree, even mainstream discourses during the Cold War era. Though liberals often shied from the term "empire" since it raised questions about the legitimacy of the Soviet state, conservatives and moderates deployed it much more readily, and consequently references to "the Soviet empire," "the last empire," and "Red imperialism" abounded. (In 1983, US President Ronald Reagan famously added "evil empire" to the list.) In this regard, from a Western Cold Warrior's perspective, in particular from a US Cold Warrior's perspective, there was nothing necessarily surprising about the anti-imperial critique that began to develop in Soviet society during the Gorbachev era since the critique was perceived as entirely correct. The shocking part was that Gorbachev was allowing the critique to appear and, very importantly, that it began rapidly acquiring serious political implications. This was utterly unprecedented and caught Western experts unprepared because, for all that rhetorical references to the USSR as an empire were familiar, deeper attention to Soviet nationality questions was not. Most Western experts on the USSR were Russian specialists. They did not know other Soviet languages and had little feel for the complex topography of nationality issues within the Soviet state. Consequently, when the Soviet order collapsed in 1991, in part due to unresolved nationality tensions and pressures, they were as stunned as anyone.

Flowing from this, arguably the most significant problem that has engaged Western experts on Russia and the Soviet Union since 1991 is to explain the remarkable development of the Soviet collapse. Why did a multinational union that had existed for over 
seventy years seemingly suddenly fall apart? What made nationality such an explosive force during the glasnost' years? How were national and ethnic identities mobilized? Did nationalism undo the Soviet state and if it did, did it have to? That is, could nationalism have been anything other than a disintegrationist force? Could the Soviet government have reacted differently and survived?

Of the various approaches to these issues taken in the field, one of the most important thus far has pointed to the unwitting role the structure of the Soviet state played in its own demise. As scholars writing in this "institutionalist" suggest, the USSR was created to function as an "ethno-federal state" - that is, as a "federal political system in which territorial administrative units [would be] invested with ethnic character"7. According to this design, theoretically at least, every Soviet national group was to receive its own territory, and living that way, the expectation, of course, was that all the groups would then live happily together. Yet, as scholars such as Valerie Bunce and Rogers Brubaker have argued, when subject to external pressures, it is precisely this type of ethno-federal structure that is most likely to weaken and come undone. That is, this type of structure appears considerably more susceptible to disintegrationist tensions, it would seem, than the structure of unitary states, even ones with mixed populations. Thus ethnically divided but unitary Romania managed to survive its rocky "post-Communist transition" in one piece, while the USSR, Czechoslovakia, and Yugoslavia all fell apart.

In a series of influential articles from the late 1990s, Philip G. Roeder laid out a now widely accepted two-step view of how this process of state devolution unfolded in the Soviet case. First, during what we could call Stage One, the early elaboration of an ethno-federal structure for the USSR creates the unintended effect of reinforcing ethnic identities and practices. This process of ethnic reinforcement then proceeds apace, passing through varying levels of intensity, over the course of subsequent decades, eventually building to the point of saturating the entire ethno-territorial framework with sub-Union-level national meaning. Then during Stage Two, as the tumultuous reforms of the glasnost' and perestroika period begin, they, again unwittingly, inject enormous instability into the ethno-federal system and end up giving regional leaders both the room and the material incentive they need "to play the ethnic card" and gradually syphon off power from Moscow ${ }^{9}$. A design meant to keep all the ethnicities united around the center thus unintentionally ushers in a dynamic that allows the ethnicities - or rather the leaders claiming to speak for them - to ignore the center and go their own way. Since the appearance of Roeder's work, other scholars have amplified and added their own elaborations to this basic institutionalist interpretation ${ }^{10}$.

In a somewhat different vein, Henry E. Hale has argued that a key ingredient in the break-up of the USSR was the existence of the Russian Federation as a "core ethnic region" within the state. As he notes: "Core ethnic regions [within ethno-territorial federations] tend to promote state break-up because they facilitate dual sovereignty, exacerbate the security fears of minority-group regions, and promote the 'imagining' of core-group identifications independent of the federation. For the USSR, this proved a deadly combination"11. Though Hale stops short of saying it, the stark fact of the existence of this ethnic Russian "core" at the center of the state also served as a reminder ton onRussians of their country's powerful resemblance to an archetypal empire consisting of an imperial metropole on the one hand and subordinate colonies on the other. As 
it turns out, the USSR was not an archetypal empire but rather a quite unusual and paradoxical one. But perceptions matter. Given the chance to see the Russian ethnic core as would-be imperial metropole, it was relatively easy for non-Russians to take the next step and see themselves as the exploited periphery. Gorbachev's democratic reforms then provided the final touch by providing non-Russian nationalists the space they needed to turn their perceptions into anti-state agitation.

If one line of research has emphasized how the ethno-federal structures and institutions helped weaken the Soviet state, other work has emphasized the effect of the nationalist discourses that were so powerful at the time. Descriptions of Soviet nations "awakening," "rising," or "coming out of the refrigerator" were common in the perestroika years, deployed almost as readily by scholars as by nationalist organizers, all of which tended to underscore the view that the 1980s USSR had always been a country of "captive peoples" who were finally doing what they had surely wanted to do all along, which was to insist on revamping the Soviet system to provide them with genuine national autonomy or, alternatively, to reject the system altogether and declare political independence $^{12}$. If social scientists were writing this way, it was in large part because they were echoing the broader nation-laden discourses of the time, which represented nations as objective facts and human-like historical actors. The democratic reforms of glasnost' were allowing the Soviet nations to "wake up" and "find their voice." It followed, then, that they would quickly get out of bed and spring into action.

Since 1991, however, this essentialist view of the operations of nationality has been drastically revised and the norm today is to see national mobilization as the product of a much more complicated process of sociocultural invention and wily adaptation to political circumstance. In effect, primordialism - the view that nations are natural and permanent - has been largely displaced by constructivism - the view that nations are contingent and historical. Thus, rather than a scenario in which nations suddenly "come to life" thanks to Gorbachev's reforms, scholars explain the intensity of nationalist mobilization during the glasnost' years as a function of nationalist organizers taking advantage of the shared space of the USSR to borrow and diffuse nationalist "ideas and methods of action." The basic ethno-territorial structure of the state clearly played a key role in creating these national attachments, but so, too, did responses to concrete events, such as violent anti-nationalist crackdowns by Soviet authorities in the Baltic region and flare-ups of interethnic violence in the Caucasus, which then ricocheted, creating a "tidal movement" of national tactical interventions and protests across what was still a common "political environment." In other words, structure was critical but so, too, was agency — indeed, the two are inherently linked and played inseparable roles within the dynamic that helped produce the Soviet collapse ${ }^{13}$.

Finally, history was also important. The legacy of the Baltic republics' political independence during the interwar period, for example, played a key role in legitimating Estonian, Latvian, and Lithuanian calls for autonomy and later for outright secession from the USSR in the late 1980s. ${ }^{14}$ Deep resentments over the Nazi-Soviet Non-Aggression Pact, which ultimately paved the way to the Soviet annexation of the Baltic in 1939-1940, boiled furiously during the perestroika years once the Secret Protocols were published ${ }^{15}$. These passions were symptomatic of the way in which historical grievance helped to fuel much of the fire that would eventually burn through the USSR's "communal apartment." 
Even the Russians, the would-be "leading nationality" of the state, carried grievances against the Soviet order, since many Russian nationalists were convinced that their people had suffered as much, if not more, than anyone else from the crimes and indignities of the Communist system ${ }^{16}$. Indeed, perceptions of history mixed and matched with multiple other regional factors, even factors of daily life at the local level, to transform the USSR of the late perestroika years into a generalized field of mobilized nationality. It was very difficult not to be political during the perestroika years - and being political at the time meant, in effect, being and acting in national terms. The most sophisticated analyses of the perestroika years now take all of these factors into account to explain why ethnic mobilization proved to be such an important factor in the demise of the USSR ${ }^{17}$.

\section{From Soviet Pseudo-Federalism to Something New? Questions of Federal Structure and Separatism in the Yeltsin and Putin Eras}

Emerging from the undoing of the Soviet Union in late December 1991, the newly independent Russian Federation faced a raft of existential questions. How would power be shared between the state's different ethnic communities? What would - or should be the proper relationship between center and periphery? Where would meaningful sovereignty reside - in Moscow or in the provinces and republics? As a result of the break-up of the Soviet state, some 25 million ethnic Russians now found themselves outside their supposed homeland - what would happen to them? Lastly, how would newly independent Russia manage the powerful crosscurrents of ethnic nationalism that had been such a creative-destructive force in the last years of perestroika? The process of "ethno-fracturing" that broke up the Soviet Union did not necessarily have an obvious end point. The American political scientist lan Bremmer coined the expression "matrioshka nationalism" to describe the ever smaller national units that might continue to split off from the new states of Eurasia, like one matrioshka doll emerging from another ${ }^{18}$. Was the new Russia fated to crack up into ever smaller states the same way that Russian independence was itself created by the disintegration of the USSR?

Such questions were indeed asked at the time, all of which helps to explain the anxieties about separatism that stirred so uncomfortably in Russian life in the early post-Soviet years. But at the same time, the new Russia was, in fact, quite different from the USSR that had preceded it, and by comparison, there was much more holding it together. For one, its population was far more ethnically homogenous. Ethnic Russians constituted the overwhelming majority of the Russian Federation's population at the time of independence - over $80 \%$. (By contrast, they made up less than $50 \%$ of the Soviet population at the time.) The territory of the Russian state was also more uniform in terms of national administration. Only about $30 \%$ of Russian state territory fell within the borders of national republics, such as Tatarstan or Yakutia, and such national areas accounted for only about $20 \%$ of the state population. The vast share of the country's territory and people were distributed between administrative units that were not just majority Russian but vastly so. In 1996, of the 21 national republics in the country, the titular national group represented a majority in only 5 (Tuva, Chechnya, Ingushetia, North Ossetia, and the Chuvash Republic). In all the others, Russians were either a majority or a plurality. All this meant that the issue of nationality was likely to figure differently in Russian politics than it had in the former USSR ${ }^{19}$. 
Still, the great questions of the early life of the new federation have turned very much on how the national and regional diversities of the state were to work together, and consequently, these have also been the central questions of Western scholarship. Russian politics in the post-Soviet period has been dominated by two figures - Boris Yeltsin (President: 1991-1999) and his successor, Vladimir Putin, who has served continuously as either Prime Minister or President since 1999. Generally speaking, Yeltsin is identified with what could be called the "soft" course on issues of national and regional autonomy, Putin with a "hard" one. Yeltsin was thus a "de-centralizer," ready to hand away power to the regions, while Putin has proven to be the opposite - a committed "centralizer" intent on consolidating a de facto unitarian state based on a strict "vertical of power" even while granting degrees of regional and national autonomy in certain areas, such as language and religious policy. Moving beyond these general differences, however, it becomes clear that neither Yeltsin the would-be champion of federalism nor Putin the apparent anti-federalist have been able to create truly institutionalized solutions for addressing Russia's national and regional diversity. Putin's "federalism-lite" rests more on his personal authority than on the rule of law, while Yeltsin's pro-federalist stance also frequently flaunted the Russian constitution. And each leader, the "soft" and the "hard," found himself drawn into brutal and costly wars in Chechnya. The region is stable today, but it would be hard to read the Chechen case as a success story of either centralization or federalism. Most of the issues there have been frozen rather than resolved.

Overall, Western scholars (as I've suggested here) have been skeptical of a genuine interest on the part of either the Yeltsin or the Putin administrations in building a lawbased federal structure that might be able to address some of the glaring socioeconomic, constitutional, and political asymmetries of Russia's post-Soviet landscape. By the same token, it's important to note that specialists in the West are themselves hardly without fault. Western studies often credit Moscow with greater power over events than it actually commands, and they have committed their own sins of mistaken emphasis, such as the tendency in the 1990s to exaggerate the threat of separatism in Russia to the point, in some cases, of foreseeing imminent national collapse ${ }^{20}$.

The best contributions to Western research on ethnic and federal questions in postSoviet Russia, by contrast, have avoided making sweeping prognostications and have focused instead on smaller-scale work - studies of regions and topical case-studies, in particular - which highlight the full complexity of Russia's ethno-territorial mosaic. For example, the field now has a number of excellent studies of nationality policy that examines issues such as the 1993 constitution and the new internal passport law of 1997, which removed the requirement that Russian citizens indicate their personal ethnicity in the document - the famous "Line Five" of the old Soviet passport ${ }^{21}$. Western scholars have also produced sound studies of national republics such as Tatarstan and Yakutia, as well comparisons between national regions that expose the nitty-gritty differences that have produced greater or lesser sympathy for separatism in one territory versus another ${ }^{22}$. Some of the research on the wars in Chechnya is also first-rate ${ }^{23}$, as are studies on the identity politics and larger policy questions connected to the Russian diaspora in the "near abroad" 24 .

By far the greatest concentration of work, however, has focused on the relationship between the center and the regions - in effect, on questions of Russian federalism or, 
if federalism is not the right thing to call it, then the evolving quasi-federal order. The Russian state inherited its federal structure from the former USSR, but that structure was largely a mirage. As the British political scientist Cameron Ross noted (trenchantly) ten years ago, "Although the USSR was formally a federation, and the Russian Soviet Federative Socialist Republic (RSFSR) was a 'federation within a federation,' in reality, Soviet federalism was a sham." Ross then goes on to quote a candid admission from a speech on nationality policy that Gorbachev gave to the Politburo in 1989: "Up to now our state has existed as a centralized and unitary state and none of us yet has the experience of living in a federation"25. Seen in this light, the apparent zig-zag from the early-to-mid 1990s when Yeltsin busily signed bilateral treaties with the regions and famously offered them "as much autonomy as [they] could swallow," to the "recentralizing" approach underway today under Putin is readily understandable - all of it is part of muddling through an imperfect Soviet legacy. And indeed much of the Western scholarship seems to approach the question from this vantage ${ }^{26}$, with some of the most suggestive research adopting an explicitly comparative perspective ${ }^{27}$.

While political scientists have focused largely on questions related to political organization, anthropologists, historical sociologists, and specialists in cultural and religious studies have examined the two other great preoccupations that tend to dominate the field of nationality studies - research on (1) the development and expression of national and ethnic identities; and (2) on the patterns and practices of interethnic relations. While the scholarship is vast and defies easy generalization, much of it draw son various shades of constructivist and institutionalist theory common to social science fields in the Western academy. Accordingly, here, too, nationality/ethnicity generally appear as constructed rather than primordial categories, with the emphasis falling on understanding identity and intergroup relations as contextual and performative - that is, as forms of personal and collective expression that are often "acted out" through one form or another of ritualized behavior and unavoidably shaped by power relations ${ }^{28}$.

What becomes clear from even a brief investigation of the scholarship on post1991 Russian identities is that just as Soviet federalism left a contradictory legacy for the post-Soviet age, the Soviet legacy of identity politics was just as jumbled and confusing. Though the Soviet state clearly went to great lengths to promote a socialist vision rooted in "ethnic particularism," the model for this particularism proved to be incomplete and in key respects superficial. Thus by the late Soviet period, Mari villagers in the Volga region or Yakuts working on collective farms in Eastern Siberia were expected to look their respective "national" parts, with the flags, cuisines, adapted Cyrillic alphabets, and dance ensembles to prove it. Yet the broader Soviet culture they were supposed to identify with was overwhelmingly Russian, including Russian or Russianized cultural figures, such as Pushkin, Tchaikovsky, and Sholokhov, and highly Russian symbols of Soviet victory or ingenuity, like the massive Rodina-Mat' statue in Volgograd (Stalingrad) or the iconic TV Red Army spy Colonel Maksim Isaev operating under cover as Nazi officer Max Otto von Stierlitz. The pressures faced by non-Russians to assimilate varied considerably from period to period, as well as from group to group and context to context, but the idea, if you were a non-Russian, that being familiar with Russian ways was a good thing - this simple fact remained a constant across the Soviet decades. A presumption of Russification was inscribed in the Soviet system ${ }^{29}$. 
Western research on national identities in post-Soviet Russia suggests that this is still very much the case. Not surprisingly, given its large Russian majority, the dominant archetypes of state-supported culture and patriotism in Russia today are preponderantly ethnically Russian and Russocentric, while Putin, the number one "state servitor" and surely the most prominent symbol of the new Russia ${ }^{30}$, presents the ultimate representation of a conscientious Russian everyman: though never forgetting to express respect for "Russia's multinational heritage," his political charisma is premised on presenting himself as an ethnic Russian rather than, say, as worldly European cosmopolitan or even a multicultural Russian "Soviet."

New research on nationalism - state-based and ethnic - and on the politics of citizenship in post-1991 Russia points to the naturalizing effect of public Russian culture in what is now a far less non-Russian country than at any point since the eighteenth century and suggests that one of the state's goals in promoting such a Russian-centered patriotism is "to weaken the [non-Russian] ethno-national demands that marked the democratic experiments of the [early] post-Soviet period" ${ }^{31}$. Scholars see a similarly nationally Russian motif at work in the careful appropriation of Soviet-lite symbolism under Putin $^{32}$. (The same is true in an even more obvious sense of symbols borrowed from the tsarist era.) Much attention has been paid to rightist national thought, in particular, to the programs of neo-Eurasianists like Aleksandr Dugin ${ }^{33}$; and to the blend of "sub-national" and national identities that blend together within certain ways of "being Russian," for example, among the country's various Cossack communities ${ }^{34}$.

Overlapping with scholarship on Russian national and ethnic identity, the study of religious identity also represents a vibrant research area. Work on the considerable Orthodox revival of the last two decades, both as a matter of personal faith and as an institutional and political dynamic, has produced impressive material, including a burgeoning discussion of desecularization as an analytic for making sense of the rise in the power of the Russian Church ${ }^{35}$. Beyond resurgences of Russianness and Orthodoxy, however, Russia today is home to the new beginnings of multiple other faiths. Consequently, recent scholarship has explored these revivals as well, examining questions of identity and policy among Russian $\mathrm{Jews}^{36}$, Muslims ${ }^{37}$, Buddhists ${ }^{38}$, and well as the followers of New Age religions ${ }^{39}$.

Along with the revival of these faiths and questions of identity, scholars have also increasingly explored conflicts on religious and ethnic grounds, including interethnic violence, racism, religious extremism, and anti-Semitism ${ }^{40}$. Though Russia has a rich history of tolerant interethnic cohabitation and cooperation - and though these realities continue to be demonstrable features of Russian public life - it is impossible to ignore the fact that interethnic relations have generally deteriorated in Russia since the collapse of communism, in part because perceptions of who seems to deserve to belong in the state have narrowed dramatically. In his new work on interethnic relations in the North Caucasus, Andrew Marshall relays a sobering fact from surveys conducted by Levada Center in Moscow: every year since 2001 more than half of Russians polled in Center surveys have agreed with the slogan "Rossiia dlia russkikh" (Russia for ethnic Russians), and in 2012, the rate of approval for this position stood at almost two-thirds. Marshall concludes: "Such feelings are not extreme in Russia but rather are acceptable and ordinary" ${ }^{41}$. It's clear that scholars will need to continue studying this phenomenon 
of growing intolerance in the years ahead. Only by studying - and then acting on the xenophobia - will there be a chance to reverse it.

\section{Conclusion}

In sum, it's fair to say that scholarship in the West on questions of national and religious life in post-Soviet Russia, is vast and vibrant, in particular, English-language British and North American scholarship, which represents the bulk of the literature reviewed here. Though historians have made only tentative forays into research on the post-Soviet decades, political scientists, anthropologists, sociologists, and other social sciences have more than covered the terrain. At the same time, it's clear that an awareness of the historical context is critical for appreciating these issues. The ultimate irony of Soviet nationality policy was that in setting out to create a multinational union of non-nationalist nationalities, Soviet policy-makers ended up nationalizing the nationalities and sabotaging the union. The net result, by the turn of the 1990s, was a population of varying peoples living in Soviet space all of whom felt, to one degree or another, more Russian, Tatar, Ukrainian, or Uzbek than they felt or wanted to feel Soviet. Perhaps not surprisingly, the Soviet state collapsed from its own seeming obsolescence a short time later.

In the pursuit of pan-national socialist harmony, the Soviet experiment, paradoxically, drew on both virtually boundless ethnophilic enthusiasm on the one hand and remorseless anti-national violence on the other. Both these forces created powerful legacies that then coursed forward to undo the Soviet state in the perestroika years, and it's fair to say that their shadows still affect Russia today, almost a quarter century after the end of the USSR.

1 Исследование выполнено за счет гранта Российского научного фонда (проект № 15-1800119).

2 Brubaker R. Rethinking Nationhood: Nation as Institutionalized Form, Practical Category, Contingent Event // Contention. 1994. Vol. 4. No.1. P. 3.

3 Путин В.В. Россия: национальный вопрос. Независимая газета. 23.01.2012. URL: http://www.ng.ru/politics/2012-01-23/1_national.html (дата обращения: 16.04.2016).

4 The best single work on early Soviet nationality policy is: Martin T. The Affirmative Action Empire: Nations and Nationalism in the Soviet Union, 1923-1939. Ithaca, NY, London, 2001.

5 Beissinger M.R. Demise of an Empire-State: Identity, Legitimacy, and the Deconstruction of Soviet Politics // The Rising Tide of Cultural Pluralism: The Nation-State at Bay? / C. Young (ed.). Madison, 1993. P.95.

6 Lieven D. Empire: The Russian Empire and its Rivals from the Sixteenth Century to the Present. London, 2000. P. 139-140.

7 Roeder Ph. G. Soviet Federalism and Ethnic Mobilization // World Politics. 1991. Vol. 43. No. 2. P. 196-232; Hale H. E., Taagepera R. Russia: Consolidation or Collapse? // Europe-Asia Studies. 2002. Vol.54. No. 7. P. 1101-1125.

8 Brubaker R. Nationalism Reframed. Cambridge, 1996; Bunce V. Subversive Institutions: The End of the Soviet State in Comparative Perspective // Post-Soviet Affairs. 1998. Vol. 14. No.4. P. 323-354; Bunce V. Subversive Institutions: The Design and the Destruction of Socialism and the State. New York, 1999; Skalnik C. L. Democratization and Disintegration in Multinational States: The Breakup of the Communist Federations // World Politics. 1999. Vol.51. No. 1. P. 205-235.

9 Roeder Ph. G. Liberalization and Ethnic Entrepreneurs in the Soviet Successor States // The Myth of «Ethnic Conflict»: Politics, Economics and «Cultural» Violence / B. Crawford, R. D. Lipschutz (eds.). Berkeley, 1998; Roeder Ph.G. Peoples and States after 1989 // Slavic Review. 1999. Vol.58. 
No.4. P. 854-882; Roeder Ph. G. Soviet Federalism and Ethnic Mobilization // World Politics. 1991. Vol. 43. No. 2. P. 196-232.

10 See, for example: Treisman D. Russia's «Ethnic Revival»: The Separatist Activism of Regional Leaders in a Postcommunist Order // World Politics. 1997. Vol.49. No.2. P.212-249; Laitin D. The National Uprisings in the Soviet Union // Liberalization and Democratization / N. Bermeo (ed.). Baltimore, 1992. P. 139-177.

11 Hale H.E. The Makeup and Breakup of Ethnofederal States: Why Russia Survives where the USSR Fell // Perspectives on Politics. 2005. Vol. 3. No. 1. P.56.

12 For a few references to this terminology, see: Khazanov A.M. Ethnic Nationalism in the Russian Federation // Daedalus. 1997. Vol.126. No. 3. P.123; Hosking G. The Awakening of the Soviet Union. Cambridge, Mass., 1990; Senn A. E. Lithuania Awakening. Berkeley; Oxford, 1990.

13 This view is argued most persuasively by the influential work of M.R. Beissinger. See, in particular: Beissinger M.R. Nationalist Mobilization and the Collapse of the Soviet State. Cambridge, UK; New York, 2002.

14 Toward Independence: The Baltic Popular Movements / J.A. Trapans (ed.). Boulder, Colo., 1991; Lieven A. The Baltic Revolution: Estonia, Latvia, Lithuania, and the Path to Independence. New Haven; London, 1993; Senn A. E. Nationality Questions in the Baltic: The Lithuanian Example // Global Convulsions: Race, Ethnicity, and Nationalism at the End of the Twentieth Century / W. A. Van Horne (ed.). Albany, 1997. P 247-260.

15 On the curious history of how the Protocols were published first in the West and then much later in the USSR, see: Хавкин Б. К истории публикации советских текстов советско-германских секретных документов 1939-1941 // Форум новейшей восточно-европейской истории и культуры, 2007. № 1. URL: http://www1.ku-eichstaett.de/ZIMOS/forum/inhaltruss7.html (дата обращения: 16.04.2016).

${ }_{16}$ Brudny Y.M. Russian Nationalism and the Soviet State, 1953-1991. Cambridge, Mass.; London, 1998; Dunlop J.B. The Rise of Russia and the Fall of the Soviet Empire. Princeton, NJ; Chichester, 1993. See also: Dunlop J. B. The New Russian Nationalism. New York, 1985; Dunlop J. B. The Faces of Contemporary Russian Nationalism. Princeton, NJ; Guildford, 1983.

17 See, for example: Gorenburg D. Minority Ethnic Mobilization in the Russian Federation. Cambridge: Cambridge University Press, 2003; Idem. Gorenburg D. Ethnic Mobilization // Managing Ethnic Diversity in Russia / O. Protsyk, B. Harzl (eds.). New York, 2013. P. 191-214.

18 Bremmer I. Reassessing Soviet Nationalities Theory // Nations and Politics in the Soviet Successor States / I. Bremmer, R. Taras (eds). New York, 1993. P.22.

19 On these figures, see: Tolz V. Thorny Road Toward Federalism in Russia // RFE/RL Research Report. 1993. No.48. December. P. 3; Kempton D. R. The Republic of Sakha (Yakutia): The Evolution of Centre-Periphery Relations in the Russian Federation // Europe-Asia Studies. 1998. Vol. 48. No. 4. P.587-588.

20 See, for example, the following alarmist titles: Stern J. Moscow meltdown: Can Russia Survive? // International Security. 1994. Vol.18. No.4. P.40-65; Herd G.P. Russia in Crisis: The Disintegration of the Federation? // London Defence Studies Paper. 1999 (July). No. E99. P.23; Solnick S. Will Russia Survive? Center and Periphery in the Russian Federation // Post-Soviet Political Order: Conflict and State Building / B.Rubin, J.Snyder (eds.). London; New York, 1998. P. 54-74.

21 One excellent study that places these issues in a broad historical and comparative context is: Aktürk Ş. Regimes of Ethnicity and Nationhood in Germany, Russia, and Turkey. New York, 2012, in particular, P.229-260. See also: Garcelon M. Colonizing the Subject: The Genealogy and Legacy of the Soviet Internal Passport // Documenting Individual Identity: The Development of State Practices in the Modern World / J. Caplan, J. Torpey (eds.). Princeton, NJ; Oxford, 2001. P. 101-120.

22 See, for example: Gossmann A. Souveränität auf Jakutisch. Köln: Bundesinstitut für Ostwissenschaftliche und International Studien, 1997; Balzer M., Vinokurova I. Nationalism, Interethnic Relations and Federalism: The Case of Sakha Republic (Yakutia) // Europe-Asia Studies. 1996. Vol.48. No.1. P.101-120; Kempton D.R. The Republic of Sakha (Yakutia): The Evolution of Centre-Periphery Relations in the Russian Federation // Europe Asia Studies. 1996. Vol. 48. No. 4. P.587-614; Graney K.E. Of Khans and Kremlins: Tatarstan and the Future of Ethno-Federalism 
in Russia. Lanham, MD, 2009; Treisman D. Russia's «Ethnic Revival»: The Separatist Activism of Regional Leaders in a Post-Communist Order // World Politics. 1997. Vol. 49. No. 2. P.212-249.

${ }_{23}$ Dunlop J. Russia Confronts Chechnya: Roots of a Separatist Conflict. Cambridge, 1998; Lieven A. Chechnya: Tombstone of Russian Power. New Haven, 1999; Gall C., Waal Th. de. Chechnya: A Small Victorious War. London, 1997; Gilligan E. Terror in Chechnya: Russia and the Tragedy of Civilians in War. Princeton, NJ; Woodstock, 2010; German T. Russia's Chechen War. London; New York, 2003.

${ }^{24}$ Laitin D.D. Identity in Formation: The Russian-Speaking Populations in the New Abroad. Ithaca, NY, 1998; The New Diaspora: Russian Minorities in the Former Soviet Republics / V.Shlapentokh, M.Sendich, E.Payin (eds.). Armonk, NY, 1994; Khazanov A. After the USSR: Ethnicity, Nationalism and Politics in the Commonwealth of Independent States. Madison, Wis.; London, 1995; Kolsto P. Russians in the Former Soviet Republics. London, 1995; Melvin N. Russians beyond Russia: The Politics of National Identity. London, 1995; Post-Soviet Puzzles: Mapping the Political Economy of the Former Soviet Union / K. Segbers, S. Spegeleire (eds.). Baden-Baden, 1995; Brubaker R. Nationalism Reframed: Nationhood and the National Question in the New Europe. Cambridge, 1996; Smith G., Wilson A. Rethinking Russia's Post-Soviet Diaspora: The Potential for Political Mobilisation in Eastern Ukraine and North-East Estonia // Europe-Asia Studies. 1997. Vol.49. No.5. P. 845-864; Poppe E., Hagendoorn L. Types of Identification Among Russians in the Near Abroad // Europe-Asia Studies. 2001. Vol.53. No.1. P.57-71; Lowell J., Barrington W., Herron E. S., Silver B. D. The Motherland is Calling: Views of Homeland among Russians in the Near Abroad // World Politics. 2003. Vol. 55. No. 2. P. 290-313.

${ }_{25}$ Ross C. Federalism and Electoral Authoritarianism under Putin // Demokratizatsiya: The Journal of Post-Soviet Democratization. 2005. Vol.13. No. 3. P. 347-371, here P. 348.

${ }^{26}$ Konitzer A., Wegren S.K. Federalism and Political Recentralization in the Russian Federation: United Russia as the Party of Power // Publius: The Journal of Federalism. 2006. No. 36. P. 503-522. For just a small sampling of this vast literature, see: Stoner-Weiss K. Central Weakness and Provincial Autonomy: Observations on the Devolution Process Russia // Post-Soviet Affairs. 1999. Vol. 15. No. 1. P. 87-104; Solnick S. Is the Center Too Weak or Too Strong in the Russian Federation? // Building the Russian State: Institutional Crisis and the Quest for Democratic Governance / V. Sperling (ed.). Boulder, CO, 2000. P. 137-156; Treisman D. After the Deluge: Regional Crises and Political Consolidation in Russia. Ann Arbor, Mich., 1999; Lapidus G. W., Walker E. W. Nationalism, Regionalism, and Federalism: Center-Periphery Relations in Post-Soviet Russia // The New Russia: Troubled Transformation / G.W.Lapidus (ed). Boulder, Colo.; Oxford, 1995; Teague E. CenterPeriphery Relations in the Russian Federation // National Identity and Ethnicity in Russia and the New States of Eurasia / R. Szporluk (ed). Armonk, NY; London, 1994; Giuliano E. Secessionism from the Bottom Up: Democratization, Nationalism, and Local Accountability in the Russian Transition // World Politics. 2006. Vol. 58. No. 2. P. 276-310; Idem. Constructing Grievance: Ethnic Nationalism in Russia's Republics. Ithaca, NY; London, 2011.

${ }^{27}$ See, for example: Blanchard O., Shleifer A. Federalism With and Without Political Centralization: China versus Russia // Transition Economies: How Much Progress? IMF Staff Paper. Special Issue. Washington, D. C., 2001. P.171-179; Aktürk Ş. Regimes of Ethnicity and Nationhood in Germany, Russia, and Turkey. New York, 2012.

28 A few of the theoretical authorities most often cited in this literature include: Anderson B. Imagined Communities: Reflections on the Origins and Spread of Nationalism. London, 1989; Smith A.D. The Ethnic Origins of Nations. Oxford, UK; New York, 1986. Taylor Ch. Sources of the Self: The Making of the Modern Identity. Cambridge, 1994; Gellner E. Nations and Nationalism. Oxford, 1983; Ethnic Groups and the State / P. R. Brass (ed.). London, 1985; Kymlicka W. Multicultural Citizenship: A Liberal Theory of Minority Rights. Oxford, 1995; Turner V. The Ritual Process: Structure and Anti-structure. Chicago, 1969; Verdery K. What was Socialism and What Comes Next. Princeton, NJ; Chichester, 1996; Scott J.C. Seeing Like a State: How Certain Schemes to Improve the Human Condition Have Failed. New Haven, Conn.; London, 1999; and Ethnic Groups and Boundaries / F. Barth (ed.). Boston, 1969.

29 As Dmitry Gorenburg notes, rather than purely promoting non-Russian nationality: «The Soviet government pursued a dual course toward its minorities, enacting assimilationist policies 
at the same time that it maintained and even strengthened the ethnic institutions that were established in the 1920s. <...> Soviet nationalities policy constantly oscillated between the two poles of Russification and ethnophilia» (Gorenburg D. Soviet Nationalities Policy and Assimilation // Rebounding Identities: The Politics of Identity in Russia and Ukraine / B. Ruble, N. Popson, D. Arel (eds.). Washington, D. C.; Baltimore, 2006. P. 273).

${ }^{30}$ On Putin as a representative of the nation, see: March L. Russian Nationalism under Putin: A Majority Faith? // Elusive Russia: Current Developments in Russian State Identity and Institutional Reform under President Putin / K. Malfliet, R. Laenen (eds.). Leiden, 2007. P. 33-52.

${ }^{31}$ The quote here is drawn from: Daucé $F$. Patriotic Unity and Ethnic Diversity at Odds: The Example of Tatar Organisations in Moscow // Europe-Asia Studies. 2015. Vol.67. No.1. P. 81. For a range of works on post-Soviet Russian national thought and practice from different disciplinary perspectives, see: Tolz V. Conflicting Homeland Myths and Nation-State Building in Postcommunist Russia // Slavic Review. 1998. Vol.57. No.2. P.267-294; Russian Nationalism and the National Reassertion of Russia / M.Laruelle (ed.). London, 2009; Allensworth W. The Russian Question: Nationalism, Mobilization, and Post-Communist Russia. New York, 1998; Shevel O. The Politics of Citizenship in Post-Soviet Russia // Post-Soviet Affairs. 2012. Vol. 28. No.1. P.111-147; Gunnar S. Pains of Partition: Nationalism, National Identity, and the Military in Post-Soviet Russia. Oslo, 2002; Oswald I. Die Nachfahren des «homo sovieticus»: ethnische Orientierung nachdem Zerfall der Sowjet Union. Muenster; New York, 2000; Petersson B. National Self-Images and Regional Identities in Russia. Aldershot, England; Burlington, VT, 2001; Pilkington H. Migration, Displacement and Identity in Post-Soviet Russia. London, 1998; Olson L. Performing Russia: Folk Revival and Russian Identity. London, 2004.

${ }_{32}$ See the interesting reflections: Shevtsova L. Putin's Russia. (Rev. and expanded ed.). Washington, D.C., 2005. P.144-145. For references to the most recent literature on discourses of patriotism in contemporary Russia, see: Daucé F., Laruelle M., Le Huérou A., Rousselet K. Introduction: What Does It Mean To Be a Patriot? // Europe-Asia Studies. 2015. Vol. 67. No. 1. P.1-7.

${ }^{33}$ On Dugin, see: Laruelle M. Aleksandr Dugin: A Russian Version of the European Radical Right. Washington, D. C., 2006; Shlapentokh D. Dugin, Eurasianism, and Central Asia // Communist and Post-Communist Studies. 2007. Vol.40. No.2. P.143-156. For rightist nationalist thought more generally, see: Parland Th. The Extreme Nationalist Threat in Russia: The Growing Influence of Western Rightist Ideas. New York, 2005.

${ }_{34}$ Skinner B. Identity Formation in the Russian Cossack Revival // Europe-Asia Studies. 1994. Vol. 46. No. 6. P. 1017-1037; Toje H. Cossack Identity in the New Russia: Kuban Cossack Revival and Local Politics // Europe-Asia Studies. 2006. Vol. 58. No. 7. P. 1057-1077; Olson L. Performing Russia: Folk Revival and Russian Identity. London, 2004. Chapter 6.

${ }^{35}$ For a few titles from a large multidisciplinary literature, see: Papkova I. The Orthodox Church and Russian Politics. Washington D. C.; New York, 2011; Idem. The Contemporary Study of Religion, Society, and Politics in Russia: A Scholar's Reflections // Religion, State, and Society. 2013. Vol.41. No. 3. P. 244-253; Köllner T. Ritual and Commemoration in Contemporary Russia: State-Church Relationships and the Vernacularization of the Politics of Memory // Focaal: European Journal of Anthropology. 2013, Winter. Vol.67. P.61-73; Kormina J. Avtobusniki: Russian Orthodox Pilgrims. "Longing for Authenticity" // Orthodoxy, Orthopraxis, Parádosis: Eastern Christians in Anthropological Perspective / C.M. Hann, H. Goltz (eds.). Berkeley; Los Angeles, 2010. P. 267-286; Wallace L.D. The Orthodox Church and Civil Society in Russia. College Station, 2006; Garrard J., Garrard C. Russian Orthodoxy Resurgent: Faith and Power in the New Russia. Princeton, NJ; Oxford, 2008; Lisovskaya E., Karpov V. Orthodoxy, Islam, and the Desecularization of Russia's State Schools // Politics and Religion. 2010. Vol. 3. No.2. P. 276-302; Bennett B. P. Religion and Language in Post-Soviet Russia. Abingdon, Oxon; New York, 2011.

${ }^{36}$ Jewish Life after the USSR / Z. Gitelman, M.Glants, M. Goldman (eds.). Bloomington; Chesham, 2003; Gitelman Z. Jewish Identities in Postcommunist Russia and Ukraine: An Uncertain Ethnicity. Cambridge; New York, 2012; Becoming Jewish in Russia and Ukraine // New Jewish Identities: contemporary Europe and beyond / Z. Gitelman, B. Kosmin, A. Kovács (eds.). Budapest, 2003. Chapter 5; Goluboff S. L. Fistfights at the Moscow Choral Synagogue: Ethnicity and Ritual in Post-Soviet Russia // Anthropological Quarterly. 2001. Vol. 74. No. 2. P.55-71. 
${ }_{37}$ Yllmaz Y. Muslims in Contemporary Russia: Russia's Domestic Muslim Policy // European Journal of Economic and Political Studies. 2013. No. 2. P. 101-120; Pogadaev V. Islam in Russia and Russian Islam // World Journal of Islamic History and Civilization. 2012. No. 2. P. 175-281; Islam in Post-Soviet Russia: Public and Private Faces / H. Pilkington, G. Yemelianova (eds.). London, 2002; Kerimov G. Islam and Muslims in Russia since the Collapse of the Soviet Union // Religion, State and Society. 1999. No. 24. P. 183-192; Russia and Islam: State, Society and Radicalism / D. Dannreuther, L. March (eds.). New York, 2010; Walker E.W. Islam, Territory, and Contested Space in PostSoviet Russia // Eurasian Geography and Economics. 2005. Vol. 46. No.4. P.247-271; Aitamurto K. Protected and Controlled: Islam and «Desecularisation from Above» in Russia // Europe-Asia Studies. 2016. Vol.68. No.1. P. 182-202; Matsuzato K. The Regional Context of Islam in Russia: Diversities along the Volga // Eurasian Geography and Economics. 2006. Vol.47. No.4. P.449-461; Selected articles in Religion and Identity in Modern Russia: The Revival of Orthodoxy and Islam / J. Johnson, M. Stepaniants, B. Forest (eds.). Aldershot; Burlington, Vt., 2005.

38 Holland E.C. Competing Interpretations of Buddhism's Revival in the Russian Republic of Kalmykia // Europe-Asia Studies. 2015. Vol.67. No.6. P.948-969; Idem. Buddhism in Russia: Challenges and Choices in the Post-Soviet Period // Religion, State, and Society. 2014. Vol.42. No.4. P. 389-402; Fagan G. Buddhism in Post-Soviet Russia: Revival or Degeneration? // Religion, State, and Society. 2001. Vol.29. No.1. P.9-21.

39 Shterin M.S. New Religions in the New Russia // Nova Religio: The Journal of Alternative and Emergent Religions. 2001. Vol.4. No.2. P. 310-321.

40 Lehmann S.G. Inter-Ethnic Conflict in the Republics of Russia in Light of Religious Revival // Post-Soviet Geography and Economics. 1998. Vol. 39. No. 8. P.461-493; Verkhovsky A. The Role of the Russian Orthodox Church in Nationalist, Xenophobic, and Anti-Western Tendencies in Russia Today: Not Nationalism, but Fundamentalism // Religion, State, and Society. 2002. Vol. 30. No. 4. P. 333-345; Idem. Approaches to Radicalism and "Extremism" as Applied to Nationalism and Religion // Russia and Islam: State, Society and Radicalism / D. Dannreuther, L. March (eds.). New York, 2010. P.26-43; Shterin M.S., Richardson J.T. Local Laws Restricting Religion in Russia: Precursors of Russia's New National Law // Journal of Church and State. 1998. Vol. 40. No. 2. P. 319341; Sagramoso D. The Radicalisation of Islamic Salafi Jamaats in the North Caucasus: Moving Closer to the Global Jihadist Movement // Europe-Asia Studies. 2012. Vol.64. No.3. P.561-595; Ethnic Conflict in the Post-Soviet World: Case Studies and Analysis / L. Drobizheva et al. (eds.). Armonk, NY, London, 1996; reprint: New York, 2015; Foxall A. Ethnic Relations in Post-Soviet Russia: Russians and non-Russians in the North Caucasus. London, 2015.

${ }^{1}$ Foxall A. Preface // Foxall A. Ethnic Relations in Post-Soviet Russia: Russians and NonRussians in the North Caucasus. London, 2015. P.XV-XVII.

\title{
FOR CITATION
}

Sunderland W. Interethnic Relations and Nationality Policy in Post-Soviet Russia: Western Scholarship Since 1991, Modern History of Russia, no. 1, 2017, pp. 152-169.

\begin{abstract}
This essay reviews the copious scholarship on nationality policies and interethnic relations in Russia that has been published in the West since the fall of the USSR. Emphasizing English-language scholarship, the article examines the influential conceptual frameworks and key themes taken up by North American and Western European specialists in the study of Russian nationality questions, both in regard to the Russians themselves as well as the other nationalities living within the Russian Federation. The principal conclusion offered is that Western scholarship on nationality issues in post-Soviet Russia underscores the profoundly ambiguous legacy left by the Soviet period in the national arena.
\end{abstract}

Keywords: Russia, post-Soviet, nationality, interethnic relations, federalism, state policy, social identities, national culture, historiography.

Author: Sunderland W. - Ph. D., Professor, Department of History, University of Cincinnati (Cincinnati, USA); sunderwd@ucmail.uc.edu 
References:

Aitamurto K. 'Protected and Controlled: Islam and «Desecularisation from Above» in Russia', Europe-Asia Studies, 2016, vol. 68, no. 1.

Aktürk Ş. Regimes of Ethnicity and Nationhood in Germany, Russia, and Turkey (New York, 2012).

Allensworth W. The Russian Question: Nationalism, Mobilization, and Post-Communist Russia (New York, 1998).

Anderson B. Imagined Communities: Reflections on the Origins and Spread of Nationalism (London, 1989).

Balzer M., Vinokurova I. "Nationalism, Interethnic Relations and Federalism: The Case of Sakha Republic (Yakutia)," Europe-Asia Studies, 1996, vol. 48, no. 1.

"Becoming Jewish in Russia and Ukraine" in New Jewish Identities: Contemporary Europe and beyond, Ed. Z. Gitelman, B. Kosmin, A. Kovács (Budapest 2003).

Beissinger M. R. "Demise of an Empire-State: Identity, Legitimacy, and the Deconstruction of Soviet Politics," in The Rising Tide of Cultural Pluralism: The Nation-State at Bay? Ed. C. Young (Madison, 1993).

Beissinger M. R. Nationalist Mobilization and the Collapse of the Soviet State (Cambridge, UK; New York, 2002).

Bennett B. P. Religion and Language in Post-Soviet Russia (Abingdon, Oxon; New York, 2011).

Blanchard O., Shleifer A. "Federalism With and Without Political Centralization: China versus Russia," in Transition Economies: How Much Progress? IMF Staff Paper. Special Issue (Washington, D. C., 2001).

Bremmer I. "Reassessing Soviet Nationalities Theory," in Nations and Politics in the Soviet Successor States, Ed. I. Bremmer and Taras R. (New York, 1993).

Brubaker R. Nationalism Reframed Nationhood and the National Question in the New Europe (Cambridge, 1996).

Brubaker R. "Rethinking Nationhood: Nation as Institutionalized Form, Practical Category, Contingent Event," Contention, 1994, vol. 4, no. 1.

Brudny Y. M. Russian Nationalism and the Soviet State, 1953-1991 (Cambridge, Mass.; London, 1998).

Bunce V. Subversive Institutions: The Design and the Destruction of Socialism and the State (New York, 1999). Bunce V. "Subversive Institutions: The End of the Soviet State in Comparative Perspective," Post-Soviet Affairs, 1998, vol. 14, no. 4.

Daucé F. "Patriotic Unity and Ethnic Diversity at Odds: The Example of Tatar Organisations in Moscow," Europe-Asia Studies, 2015, vol. 67, no. 1.

Daucé F., Laruelle M., Le Huérou A., Rousselet K. "Introduction: What Does It Mean To Be a Patriot?" EuropeAsia Studies, 2015, vol.67, no. 1.

Dunlop J. B. The Faces of Contemporary Russian Nationalism (Princeton, N. J., 1983).

Dunlop J. B. The New Russian Nationalism (New York, 1985).

Dunlop J. B. The Rise of Russia and the Fall of the Soviet Empire (Princeton, N. J., 1993).

Dunlop J. Russia Confronts Chechnya: Roots of a Separatist Conflict (Cambridge, 1998).

Ethnic Conflict in the Post-Soviet World: Case Studies and Analysis, Ed. L. Drobizheva et al. (Armonk, N. Y.; London, 1996).

Ethnic Groups and Boundaries, Ed. F. Barth (Boston, 1969).

Fagan G. "Buddhism in Post-Soviet Russia: Revival or Degeneration?" in Religion, State, and Society, 2001, vol. 29 , no. 1 .

Foxall A. Ethnic Relations in Post-Soviet Russia: Russians and non-Russians in the North Caucasus (London, 2015).

Gall C., Waal Th. de. Chechnya: A Small Victorious War (London, 1997).

Garcelon M. "Colonizing the Subject: The Genealogy and Legacy of the Soviet Internal Passport," in Documenting Individual Identity: The Development of State Practices in the Modern World, Ed. J. Caplan and J. Torpey (Princeton, N. J.; Oxford, 2001).

Garrard J., Garrard C. Russian Orthodoxy Resurgent: Faith and Power in the New Russia (Princeton, N. J. ; Oxford, 2008).

Gellner E. Nations and Nationalism (Oxford, 1983).

German T. Russia's Chechen War (London, 2003).

Gilligan E. Terror in Chechnya: Russia and the Tragedy of Civilians in War (Princeton, N. J.; Woodstock, 2010). Gitelman Z. Jewish Identities in Postcommunist Russia and Ukraine: An Uncertain Ethnicity (Cambridge; New York, 2012). 
Giuliano E. Constructing Grievance: Ethnic Nationalism in Russia's Republics (Ithaca; London, 2011).

Giuliano E. "Secessionism from the Bottom Up: Democratization, Nationalism, and Local Accountability in the Russian Transition," World Politics, 2006, vol. 58, no 2.

Goluboff S. L. "Fistfights at the Moscow Choral Synagogue: Ethnicity and Ritual in Post-Soviet Russia," Anthropological Quarterly, 2001, vol. 74, no 2.

Gorenburg D. "Ethnic Mobilization," in Managing Ethnic Diversity in Russia, Ed. O. Protsyk and B. Harzl (New York, 2013).

Gorenburg D. Minority Ethnic Mobilization in the Russian Federation. (Cambridge, 2003).

Gorenburg D. "Soviet Nationalities Policy and Assimilation," in Rebounding Identities: The Politics of Identity in Russia and Ukraine, B. Ruble, N. Popson, D. Arel (eds.). Washington, D. C., 2006).

Gossmann A. Souveränität auf Jakutisch (Köln, 1997).

Graney K. E. Of Khans and Kremlins: Tatarstan and the Future of Ethno-Federalism in Russia (Lanham, MD, 2009).

Gunnar S. Pains of Partition: Nationalism, National Identity, and the Military in Post-Soviet Russia (Oslo, 2002).

Hale H. E. "The Makeup and Breakup of Ethnofederal States: Why Russia Survives Where the USSR Fell," Perspectives on Politics, 2005, vol. 3, no. 1.

Hale H. E., Taagepera R. "Russia: Consolidation or Collapse?" Europe-Asia Studies, 2002, vol. 54, no. 7.

Herd G. P. "Russia in Crisis: The Disintegration of the Federation?" London Defence Studies Paper, 1999 (July), vol. 23, no. E99.

Holland E. C. "Buddhism in Russia: Challenges and Choices in the Post-Soviet Period," Religion, State, and Society, 2014, vol. 42, no. 4.

Holland E. C. "Competing Interpretations of Buddhism's Revival in the Russian Republic of Kalmykia," EuropeAsia Studies, 2015, vol.67, no. 6.

Hosking G. The Awakening of the Soviet Union (Cambridge, Mass., 1990).

Islam in Post-Soviet Russia: Public and Private Faces, Ed. H. Pilkington, G. Yemelianova. (London, 2002).

Jewish Life after the USSR, Ed. Z. Gitelman, M. Glants, M. Goldman (Bloomington, Ind.; Chesham, 2003).

Kempton D. R. "The Republic of Sakha (Yakutia): The Evolution of Centre-Periphery Relations in the Russian Federation," Europe-Asia Studies, 1998, vol. 48, no. 4.

Kerimov G. "Islam and Muslims in Russia since the Collapse of the Soviet Union," Religion, State and Society. 1999. No. 24.

Khavkin B. "K istorii publikatsii sovetskikh tekstov sovetsko-germanskikh sekretnykh dokumentov 1939-1941," Forum noveishei vostochnoevropeiskoi istorii i kul'tury, 2007, n.1 (http://www1.ku-eichstaett.de/ZIMOS/forum/inhaltruss7.html; last consulted: April 2016).

Khazanov A. After the USSR: Ethnicity, Nationalism and Politics in the Commonwealth of Independent States (Madison, Wis.; London, 1995).

Khazanov A. M. "Ethnic Nationalism in the Russian Federation," Daedalus, 1997, vol. 126, no. 3.

Köllner T. "Ritual and Commemoration in Contemporary Russia: State-Church Relationships and the Vernacularization of the Politics of Memory," Focaal: European Journal of Anthropology, 2013 (Winter), vol. 67.

Kolsto P. Russians in the Former Soviet Republics (London, 1995).

Konitzer A., Wegren S. K. "Federalism and Political Recentralization in the Russian Federation: United Russia as the Party of Power," Publius: The Journal of Federalism. 2006. No. 36.

Kormina J. "Avtobusniki: Russian Orthodox Pilgrims. Longing for Authenticity," in Orthodoxy, Orthopraxis, Parádosis: Eastern Christians in Anthropological Perspective, Ed. C. M. Hann, H. Goltz (Berkeley; Los Angeles, 2010).

Kymlicka W. Multicultural Citizenship: A Liberal Theory of Minority Rights (Oxford, 1995).

Laitin D. D. Identity in Formation: The Russian-Speaking Populations in the New Abroad. Ithaca, NY, 1998.

Laitin D. "The National Uprisings in the Soviet Union," in Liberalization and Democratization, Ed. N. Bermeo (Baltimore, 1992).

Lapidus G.W., Walker E.W. "Nationalism, Regionalism, and Federalism: Center-Periphery Relations in PostSoviet Russia," in The New Russia: Troubled Transformation, Ed. G. W. Lapidus (Boulder, Colo., 1995). Laruelle M. Aleksandr Dugin: A Russian Version of the European Radical Right (Washington, D. C., 2006). Lehmann S. G. "Inter-Ethnic Conflict in the Republics of Russia in Light of Religious Revival," Post-Soviet Geography and Economics, 1998, vol. 39, no 8.

Lieven A. Chechnya: Tombstone of Russian Power (New Haven, 1999). 
Lieven A. The Baltic Revolution: Estonia, Latvia, Lithuania, and the Path to Independence (New Haven; London, 1993).

Lieven D. Empire: The Russian Empire and its Rivals from the Sixteenth Century to the Present (London, 2000).

Lisovskaya E., Karpov V. "Orthodoxy, Islam, and the Desecularization of Russia's State Schools," Politics and Religion, 2010, vol. 3, no. 2.

Lowell J., Barrington W., Herron E. S., Silver B. D. "The Motherland Is Calling: Views of Homeland among Russians in the Near Abroad," World Politics, 2003, vol. 55, no. 2.

March L. "Russian Nationalism under Putin: A Majority Faith?" in Elusive Russia: Current Developments in Russian State Identity and Institutional Reform under President Putin. Ed. K. Malfliet, R. Laenen (eds.) (Leiden, 2007).

Martin T. The Affirmative Action Empire: Nations and Nationalism in the Soviet Union, 1923-1939 (Ithaca, NY; London, 2001).

Matsuzato K. "The Regional Context of Islam in Russia: Diversities along the Volga," Eurasian Geography and Economics, 2006, vol.47, no. 4.

Melvin N. Russians beyond Russia: The Politics of National Identity (London, 1995).

Olson L. Performing Russia: Folk Revival and Russian Identity (London, 2004).

Oswald. I. Die Nachfahren des 'homo sovieticus': ethnische Orientierungnachdem Zerfall der Sowjet Union (Muenster; New York, 2000).

Papkova I. "The Contemporary Study of Religion, Society, and Politics in Russia: A Scholar's Reflections," Religion, State, and Society, 2013, vol. 41, no. 3.

Papkova I. The Orthodox Church and Russian Politics (Washington D. C.; New York, 2011).

Parland Th. The Extreme Nationalist Threat in Russia: The Growing Influence of Western Rightist Ideas (New York, 2005).

Petersson B. National Self-Images and Regional Identities in Russia (Aldershot, Eng.; Burlington, VT, 2001).

Pilkington H. Migration, Displacement and Identity in Post-Soviet Russia (London, 1998).

Pogadaev V. "Islam in Russia and Russian Islam," World Journal of Islamic History and Civilization. 2012. No. 2. Poppe E., Hagendoorn L. "Types of Identification among Russians in the Near Abroad," Europe-Asia Studies, 2001, vol. 53, no.1.

Post-Soviet Puzzles: Mapping the Political Economy of the Former Soviet Union, Ed. K. Segbers and S. De Spegeleire (eds.) (Baden-Baden, 1995).

Putin V. "Rossiia: National'nyi vopros," Nezavisimaia gazeta, 23.01.2012 (http://www.ng.ru/politics/2012-01-23/1_national.html; last accessed: April 2016).

Religion and Identity in Modern Russia: The Revival of Orthodoxy and Islam. Ed. J. Johnson, M. Stepaniants, B. Forest (Aldershot; Burlington, Vt., 2005).

Roeder Ph. G. "Liberalization and Ethnic Entrepreneurs in the Soviet Successor States," The myth of "ethnic conflict": politics, economics and "cultural" violence, Ed. B. Crawford and R. D. Lipschutz (Berkeley, Calif., 1998).

Roeder Ph. G. "Peoples and States after 1989," Slavic Review, 1999, vol. 58, no. 4.

Roeder Ph. G. "Soviet Federalism and Ethnic Mobilization," World Politics, 1991, vol. 43, no. 2.

Ross C. "Federalism and Electoral Authoritarianism under Putin," Demokratizatsiya: The Journal of Post-Soviet Democratization, 2005, vol. 13, no. 3.

Russia and Islam: State, Society and Radicalism, Ed. D Dannreuther and L. March (New York: Routledge, 2010).

Russian Nationalism and the National Reassertion of Russia, Ed. M. Laruelle (London, 2009).

Sagramoso D. "The Radicalisation of Islamic Salafi Jamaats in the North Caucasus: Moving Closer to the Global Jihadist Movement," Europe-Asia Studies, 2012, vol. 64, no. 3.

Scott J. C. Seeing Like a State: How Certain Schemes to Improve the Human Condition Have Failed (New Haven, Conn.; London, 1999).

Senn A. E. Lithuania Awakening (Berkeley; Oxford, 1990).

Senn A. E. "Nationality Questions in the Baltic: The Lithuanian Example," in Global Convulsions: Race, Ethnicity, and Nationalism at the End of the Twentieth Century, Ed. W. A. Van Horne (Albany, 1997).

Shevel O. "The Politics of Citizenship in Post-Soviet Russia," Post-Soviet Affairs, 2012, vol. 28, no. 1.

Shevtsova L. Putin's Russia (Rev. and expanded ed.). Washington, D. C., 2005). 
Shlapentokh D. "Dugin, Eurasianism, and Central Asia," Communist and Post-Communist Studies, 2007, vol. 40 , no. 2.

Shterin M. S. "New Religions in the New Russia," Nova Religio: The Journal of Alternative and Emergent Religions, 2001, vol. 4, no. 2.

Shterin M.S., Richardson J. T. "Local Laws Restricting Religion in Russia: Precursors of Russia's New National Law," Journal of Church and State, 1998, vol. 40, no. 2.

Skalnik C. L. "Democratization and Disintegration in Multinational States: The Breakup of the Communist Federations," World Politics, 1999, vol. 51, no. 1.

Skinner B. "Identity Formation in the Russian Cossack Revival," Europe-Asia Studies, 1994, vol. 46, no. 6.

Smith A. D. The Ethnic Origins of Nations (Oxford, UK; New York, NY, 1986).

Smith G., Wilson A. "Rethinking Russia's Post-Soviet Diaspora: The Potential for Political Mobilisation in Eastern Ukraine and North-East Estonia," Europe-Asia Studies, 1997, vol. 49, no. 5.

Solnick S. "Is the Center Too Weak or Too Strong in the Russian Federation?" in Building the Russian State: Institutional Crisis and the Quest for Democratic Governance, Ed. V. Sperling (Boulder, CO, 2000).

Solnick S. "Will Russia Survive? Center and Periphery in the Russian Federation," Post-Soviet Political Order: Conflict and State Building, in B. Rubin, J. Snyder (London; New York, 1998).

Stern J. "Moscow meltdown: Can Russia Survive?" International Security, 1994, vol. 18, no. 4.

Stoner-Weiss K. "Central Weakness and Provincial Autonomy: Observations on the Devolution Process Russia," Post-Soviet Affairs, 1999, vol. 15, no. 1.

Taylor Ch. Sources of the Self: The Making of the Modern Identity (Cambridge, 1994).

Teague E. "Center-Periphery Relations in the Russian Federation," in National Identity and Ethnicity in Russia and the New States of Eurasia, Ed. R. Szporluk (Armonk, N. Y.; London: M. E. Sharpe, 1994).

The New Diaspora: Russian Minorities in the Former Soviet Republics Ed. V. Shlapentokh, M. Sendich, E Payin (Armonk, N.Y., 1994).

Toje H. "Cossack Identity in the New Russia: Kuban Cossack Revival and Local Politics," Europe-Asia Studies, 2006, vol. 58 , no. 7 .

Tolz V. Conflicting 'Homeland Myths and Nation-State building in Postcommunist Russia," Slavic Review, 1998, vol. 57, no. 2 .

Tolz V. "Thorny Road toward Federalism in Russia," RFE/RL Research Report, 1993, no. 48, December 2, 4, 3. Toward Independence: The Baltic Popular Movements, Ed. J. A. Trapans (Boulder, Colo.: Westview, 1991) Treisman D. After the Deluge: Regional Crises and Political Consolidation in Russia (Ann Arbor, Mich., 1999). Treisman D. "Russia's 'Ethnic Revival': The Separatist Activism of Regional Leaders in a Postcommunist Order," World Politics, 1997, vol. 49, no 2.

Turner V. The Ritual Process: Structure and Anti-Structure (Chicago Co., 1969).

Verdery K. What Was Socialism and What Comes Next (Princeton, N. J., 1996).

Verkhovsky A. "Approaches to Radicalism and 'Extremism' as Applied to Nationalism and Religion," in Russia and Islam: State, Society and Radicalism, Ed. D. Dannreuther, L. March (New York, 2010).

Verkhovsky A. "The Role of the Russian Orthodox Church in Nationalist, Xenophobic, and Anti-Western Tendencies in Russia Today: Not Nationalism, but Fundamentalism," Religion, State, and Society, 2002, vol. 30, no. 4 .

Walker E. W. "Islam, Territory, and Contested Space in Post-Soviet Russia," Eurasian Geography and Economics, 2005, vol. 46, no. 4.

Wallace L. D. The Orthodox Church and Civil Society in Russia (College Station, 2006).

Yılmaz Y. "Muslims in Contemporary Russia: Russia's Domestic Muslim Policy," European Journal of Economic and Political Studies, 2013, no 2. 